\title{
Gender Difference and Bullying among Secondary School Students in Palestine
}

\author{
Ahmad Hanani ${ }^{1}$, Metin Piskin ${ }^{2}$ \\ ${ }^{1}$ An-Najah National University, Nablus, Palestine \\ ${ }^{2}$ Ankara University, Ankara, Turkey \\ Email: ahmadhnn@gmail.com
}

How to cite this paper: Hanani, A., \& Piskin, M. (2020). Gender Difference and Bullying among Secondary School Students in Palestine. Open Journal of Depression, 9, 95-100.

https://doi.org/10.4236/ojd.2020.94009

Received: September 18, 2020

Accepted: November 27, 2020

Published: November 30, 2020

Copyright $\odot 2020$ by author(s) and Scientific Research Publishing Inc. This work is licensed under the Creative Commons Attribution International License (CC BY 4.0).

http://creativecommons.org/licenses/by/4.0/ (c) (i) Open Access

\begin{abstract}
Background: Bullying in schools is the problem and an issue of every nation around the globe. Researchers around the globe pointed out an abundance of negative impacts on students involved in bullying and require the focus and attention of adults to address and resolve bullying incidents among students. Aim: This research aimed to study the impact of bullying on gender of secondary school students in Palestine. Methods: The present mixed-method study was directed on samples randomly and total number of samples was 827 students (the male was 388 and female was 439). Bullying was assessed by using Bully Victim Determination Scale, developed by Piskin \& Ayas (2007). Result: After analyzing data by using the Mann Whitney U test, it was found that male students are more bullied than females. Conclusion: The study concluded that girls and boys are vulnerable to bullying. But the boys are found to be more bullied than girls.
\end{abstract}

\section{Keywords}

Bullying, Gender, Secondary School, Palestine

\section{Introduction}

Student community is one of the most important elements of the school institution. It's the backbone of the society and its future promise to maintain and care for them. Also providing all conditions and possibilities necessary for their development and protecting them from harmful influences. Therefore, the integrated and balanced attention to the service of all students leads in general to the formation of a human personality compatible in terms of mental abilities, social and psychological, which needs all school and community coordination and efforts. Despite the considerable efforts made by schools in the area of education in particular, there are some negative phenomena that affect the effectiveness of 
the educational process and the ability of its members to achieve their goal (Al-Qhatani, 2008). Schools have been always viewing as institutions to transfer knowledge and culture to the future generation. It is a dynamic human system which aims at nurturing the mutual growth and understanding between children and adults. At schools, students are the core of the system. For their great importance, adequate information about pupils is necessary for any meaningful learning process in order to save teachers' effort and change learners' in accordance with the set objectives, such factors that affect learning and teaching, including child growth, age heredity, interest, home and social effects and violence in school as well as school bullying need to be addressed (Omoniyi, 2013). Based on a research conducted in different countries, bullying is a serious issue within schools from primary to high school in many western and eastern countries. Bullying as an aggressive behavior has probably occurred as long as there have schools. However, until the pioneering work of Olweus in the 1970s, it had not received much attention. Shortly after Olweus's (1993) work in Scandinavian countries, interest in such a research spread in other countries (Piskin, 2002). Bullying and victimization are universal phenomena recognized and studied internationally. Groups of researchers around the world are concerned about these behaviours and their impact in society are conducting significant research to elucidate causes, concomitants, and outcome of bullying behaviours and victimization (Nansel et al., 2004). There is much speculation as to whether gender differences exist in bullying. A study performed by Griezel et al. (2012) aimed to determine if the rates of bullying differed between genders. The researchers used 803 students, ages ranging from 12 to 17 years old, to complete this analysis. They discovered that, "overall, boys engaged in and were the target of traditional bullying more than girls" (Griezel et al., 2012: p. 451). This finding suggests that boys not only bully more but also fall victim to bullying more so than girls. A study performed by Hoertel, Strat, Lavaud, \& Limosin (2012) found similar results. In their study, the probability of being involved in bullying was significantly higher for men than women (Hoertel et al., 2012). Additionally, Chapell et al. (2006) discovered that males bullied significantly more in both elementary and high school than female did. Findings from another study on the gender differences in bullying conducted by Crick \& Grotpeter (1995) suggested that, "both girls and boys are aggressive but tend to exhibit distinct forms of the behavior" (p. 721). This proposes that both males and females do bully at comparable rates, but the styles in which they use to bully may be different.

In 2000, Espelage et al. tested sex, grade, race, price of lunch, and poverty status as demographic variables. In their study, only sex was associated with bullying behavior, with males reporting more participation than females (2000). Nansel et al.'s study in 2001 shows the same results with respect to sex as a demographic variable, with males bullying and being bullied more than females. However, they also found some differences in bullying behaviors with respect to race that Hispanic youth reported slightly more moderate and frequent bullying than other races, and that black students reported being bullied slightly less often 
than students of other races. The findings of Seals and Young in 2003 concur with the results of both Espelage et al. in 2000 and Nansel et al. in 2001, with males reporting more bullying than females. In addition, younger students, seventh graders compared to eighth graders, participated in more bullying behaviors than older students (Seals \& Young, 2003).

In a recent study using a representative sample of 1500 Spanish students enrolled in compulsory secondary school during the 2007-2008 academic year, it was revealed that concerning bullies, boys are involved in all kinds of bullying incidents to a significantly higher degree than are girls, except in cases of indirect manifestation of the phenomenon (such as speaking ill of someone, for example) in which girls are significantly more associated with than are boys. For victims, too, the boys experience direct experiences of bullying, such as physical aggression, and girls are more involved in situations of indirect violence, such as malicious gossip (Carrera Fernández et al., 2013). Another article that reviews integrates empirical findings on the risk factors associated with bullying and peer victimization in schools, found that many studies report that boys are in general more likely to engage in bullying than girls, and boys are commonly victims and perpetrators of direct forms of bullying, while girls experience indirect bullying (Hong \& Espelage, 2012). Some researchers intrigued by the reoccurring gender differences in bullying attempted to assess why these gender differences emerge. Lagerspetz et al. (1988) proposed that females are more inclined to use indirect/relational aggression because of their social structure. For females, close and strong relationships between friends tend to emerge whereas in males larger and more diffuse social networks exist (Rivers \& Smith, 1994). Therefore, threatening or manipulating those friendships can do more harm for females than it can for males (Bjorkqvist et al., 1992; Lagerspetz et al., 1988). Additionally, females tend to have more concern for interpersonal problems which can make them more inclined to reacting negatively to relational problems (Crick et al., 2001). Females may also be predisposed to use indirect aggression because they mature faster verbally than males (Lagerspetz et al., 1988). Because females tend to acquire verbal skills at an earlier stage, the use of indirect aggression is simply facilitated (Bjorkqvist et al., 1992). In regard to males, it is a social norm for them to be aggressive and display dominance; therefore, males typically may display a more direct aggression style of bullying (Lagerspetz et al., 1988).

\section{Objectives}

To investigate the bullying and gender differences among secondary school students in Palestine.

\section{Methodology}

\subsection{Tools of Study}

Bullying was investigated by using the Bully Victim Determination Scale, devel- 
oped by Piskin \& Ayas (2007).

\subsection{Sample}

The sample for the study was taken from secondary schools in Nablus Governorate. Purposive sampling technique was used to select the participants. The total no. of participants consisted of 827 students, males $=388$, females $=439$.

\subsection{Procedure}

The data current study was collected through personal contact with the students. Before administering the tool, the purpose of the study was explained to the students and they were assured that their responses would be kept as confidential and will be used for research purpose only. They were requested to fill the bullying scale. The scale took 25 - 30 minutes to complete. In this way, the data was collected from the students. The obtained data was analyzed by the Mann Whitney $\mathrm{U}$ test used because there are male and female.

\section{Result}

According to Table 1, the Mann Whitney $U$ test, shows that all differences among male and female are significant. Male have higher score than female. The result above shows that total bullying was $\mathbf{5 0 3 . 9 8}$ for male more than female 334.47.

The result in Table 2 according to the Mann Whitney $U$ test shows that difference among male and female are significant. Male have higher score in the total of victimization. The total victimization for male was 534.78 more than female 307.25 .

\section{Conclusion}

The study concluded that bullying takes place at every phase of life. Not only the girls but boys are also vulnerable to bullying. Regarding the outcome of the current study, we find its results imitate the outputs of studies conducted in different countries of the world, about the existence of gender differences in bullying, as stated in the study of Griezel et al., 2012, that males participate in bullying and

Table 1. Bullying U-Test scores related to gender.

\begin{tabular}{ccccccc}
\hline & Group & N & Mean Ranks & Sum of Ranks & U & P \\
\hline $\begin{array}{c}\text { Total } \\
\text { Bullying }\end{array}$ & Male & 388 & 503.98 & $195,545.00$ & $50,253.00$ & 0.000 \\
\hline
\end{tabular}

Table 2. Victimization U-Test scores related to gender.

\begin{tabular}{ccccccc}
\hline & Group & N & Mean Ranks & Sum of Ranks & U & P \\
\hline $\begin{array}{c}\text { Total } \\
\text { Victimization }\end{array}$ & Male & 388 & 534.78 & $207,496.5$ & $38,301.50$ & 0.000 \\
& Female & 439 & 307.25 & $134,881.5$ & & \\
\hline
\end{tabular}


as victims, more than girls. Also, the studies Hoertel et al. (2012) and the study of Espelage \& Swearer (2003) showed results similar to those of the current study that bullying takes place in every phase of life. Boys are found to be more bullied than girls. Boys are found to be more bullied than girls.

\section{Acknowledgements}

The authors highly appreciate all colleagues who helped in distribution and allowing to do the questionnaire among the targeted students.

\section{Disclosure}

The authors report no conflicts of interest in this work.

\section{Fund}

The authors covered the research expenses by themselves and they did not receive funds for this work.

\section{Conflicts of Interest}

The authors declare no conflicts of interest regarding the publication of this paper.

\section{References}

Al-Qhatani, N. (2008). Bullying among Intermediate School Students in Riyadh City: Survey Study and a Proposal Intervention Program Suitable to School Environment in Saudi Arabian. Unpublished Dissertation, The Kingdom Saudi Arabia: King Saud University.

Bjorkqvist, K., Lagerspetz, K. M. J., \& Kaukiainen, A. (1992). Do Girls Manipulate and Boys Fight? Developmental Trends in Regard to Direct and Indirect Aggression. Aggressive Behaviour, 18, 117-127. https://doi.org/10.1002/1098-2337(1992)18:2<117::AID-AB2480180205>3.0.CO;2-3

Carrera Fernández, M. V., Fernández, M. L., Castro, Y. R., Failde Garrido, J. M., Otero, M. C. (2013). Bullying in Spanish Secondary Schools: Gender-Based Differences. The Spanish Journal of Psychology, 16, 1-14.

Chapell, M. S., Hasselman, S. L. Kitchin, T., Lomon, S. N., MacIver, K. W., \& Sarullo, P. L. (2006). Bullying in Elementary School, High School, and College. Adolescence, 41, 633-647.

Crick, N. R., \& Grotpeter, J. K. (1995). Relational Aggression, Gender, and Social-Psychological Adjustment. Child Development, 66, 710-722. https://doi.org/10.2307/1131945

Crick, N. R., Nelson, D. A., Morales, J. R., Cullerton-Sen, C., Casas, J. F., \& Hickman, S. E. (2001). Relational Victimization in Childhood and Adolescence: I Hurt You through the Grapevine. In J. Juvonen, \& S. Graham (Eds), Peer Harassment in School: The Plight of the Vulnerable and the Victimized (pp. 196-214). New York: Guillford Press.

Espelage, D. L., \& Swearer, S. M. (2003). Research on School Bullying and Victimization: What Have We Learned and Where do We Go from Here? School Psychology Review, 32, 365-383. https://doi.org/10.1080/02796015.2003.12086206

Griezel, L., Finger, L. R., Bodkin-Andrews, G. H., Craven, R. G., \& Yeung, A. S. (2012). Uncovering the Structure of and Gender and Developmental Differences in Cyber Bul- 
lying. The Journal of Educational Research, 105, 442-455.

https://doi.org/10.1080/00220671.2011.629692

Hoertel, N., Strat, Y. L., Lavaud, P., \& Limosin, F. (2012). Gender Effects in Bullying: Results from a National sample. Psychiatry Research, 200, 921-927.

https://doi.org/10.1016/j.psychres.2012.03.036

Hong, J. S., \& Espelage, D. L. (2012). A Review of Research on Bullying and Peer Victimization in School: An Ecological System Analysis. Aggression Violent Behavior, 17, 311-322. https://doi.org/10.1016/j.avb.2012.03.003

Lagerspetz, K. M. J., Bjorkqvist, K., \& Peltonen, T. (1988). Is Indirect Aggression Typical of Females? Gender Differences in Aggressiveness in 11 to 12 -Year-Old Children. Aggressive Behavior, 14, 403-414.

https://doi.org/10.1002/1098-2337(1988)14:6<403::AID-AB2480140602>3.0.CO;2-D

Nansel, T. R., et al. (2004). Cross-National Consistency in the Relationship between Bullying Behaviors and Psychosocial Adjustment. Archives of Pediatrics and Adolescent Medicine, 158, 730-736.

Olweus, D. (1993). Bully/Victim Problems among Schoolchildren: Long-Term Consequences and an Effective Intervention Program. In S. Hodgins (Ed.), Mental Disorder and Crime (pp. 317-349). Thousand Oaks, CA: Sage.

Omoniyi, M. (2013). Bullying in Schools: Psychological Implications and Counselling Interventions. Journal of Education and Practice, 18, 70-78.

Piskin, M. (2002). School Bullying: Definition, Types, Related Factors, and Strategies to Prevent Bullying Problems. Educational Sciences: Theory \& Practice, 2, 531-562.

Piskin, M., \& Ayas, T. (2007). Development of Peer Bullying Scale-Adolescent Form. Paper Presented at the 9th National Counseling and Guidance Congress. Dokuz Eylul University, Izmir: 17-19 October 2007, Turkey.

Rivers, I., \& Smith, P. K. (1994). Types of Bullying Behaviour and Their Correlates. Aggressive Behavior, 20, 359-368. https://doi.org/10.1002/1098-2337(1994)20:5<359::AID-AB2480200503>3.0.CO;2-J

Seals, D., \& Young, J. (2003). Bullying and Victimization: Prevalence and Relationship to Gender Level, Ethnicity, Self-Esteem, and Depression. Journal of Adolescence, 38, 335-747. 